\title{
НЕКОТОРЫЕ ПОДХОДЫ К ОПРЕДЕЛЕНИЮ РИСКОВ МЕДИЦИНСКОЙ СТРАХОВОЙ ДЕЯТЕЛЬНОСТИ
}

\author{
С. О. Джундубаева \\ Страховая медицинская компания АО КК ЗиМС “Интертич”, г. Алматы
}

\begin{abstract}
The risks of medical insurance activity researches are generalized. The dynamics of statistical indexes to purchase medical services for population are analyzed in the first report. The peculiarities of risk estimation in connection with the expressed vagueness of similar tasks are underlined.
\end{abstract}

Специфика медицинского страхования связана с необходимостью сложного взаимодействия страховой компании с организациями, обеспечивающими ассистанс, клиническими учреждениями, отдельными страхователями, другими организациями и физическими лицами.

Ключевым элементом в управлении рисками, как правило, является величина риска, задающаяся страховщиком на уровне, обеспечивающем его конкурентоспособность на рынке и согласующемся с требованиями Комитета финансового надзора Республики Казахстан (РК). При формировании различных программ добровольного медицинского страхования (ДМС) страховщик может регулировать ряд факторов, влияющих на стоимость полиса. Однако, на большую часть условий и факторов страховщик повлиять не в силах, так как они целиком или частично зависят от внешней среды страхования, то есть от характеристик совокупности страхователей, медицинских учреждений и страхового рынка в целом.

В результате, на рынке РК сейчас наблюдается тенденция отхода страховщиков от специализации на медицинском страховании.

Убыточность рынка ДМС, судя по динамике премий и развития убытков, за период с 2001 по 2009 гг. колеблется в пределах 70-80\%. В данный момент большая часть населения Республики Казахстан не в состоянии приобрести такую страховую услугу. Анализ рынка ДМС в РК выявил, что эта форма финансирования здравоохранения имеет небольшую долю рынка и обеспечивает медицинской помощью не более $5 \%$ населения страны. Одной из причин невозможности увеличения количества страхователей является отсутствие доступных и разнообразных страховых программ, эффективного актуарного аппарата, доступного и качественного медицинского сервиса. Весь обозначенный круг проблем, характеризующих современное состояние рынка ДМС в Казахстане, требует решения главной проблемы построения системы управления рисками в ДМС, а также изучения вклада статистических показателей (c) С. О. Джундубаева по оценке стремления населения приобрести медицинские услуги для выявления системных и случайных тенденций риска медицинской страховой деятельности.

Очевидно, что риск при медицинском страховании определяется двумя составляющими: системно-популяционными факторами и размытостью оценок состояния здоровья страхователя. Это заставляет говорить о медицинском страховании как об операции, осуществляемой в условиях неопределенности, когда вероятности возможных вариантов обстановки неизвестны. Важным представляется использование критериев, выбор каждого из которых, наряду с характером решаемой задачи, поставленных целевых установок и ограничений, зависит от склонности к риску лиц, принимающих решения.

Изучалась динамика желающих приобрести медицинские услуги, но не имеющих возможности сделать это из-за недостатка финансовых средств; не испытывающих потребности в приобретении медицинских услуг и, наконец, количество жителей, которые собирались приобрести медицинские услуги в ближайшее время.

Изменения числа жителей Казахстана, собирающихся купить медицинские услуги, подчиняются влиянию двух законов - волнообразного с колебаниями до $30 \%$ относительно первоначальной величины и тренда медленного роста числа потребителей, надеющихся улучшить состояние здоровья. Подобная тенденция поддерживается параллельным уменьшением числа жителей, не имеющих финансовых возможностей для принятия медицинских услуг.

Для выявления тенденций и оценки валидности статистических исследований применили метод анализа автокорреляционных функций. В качестве примера представим лишь один из вариантов расчета с логарифмическим преобразованием (рис. 1).

Наличие тренда и сезонная составляющая ряда выглядят очень отчетливо, равно как и соответствующие автокорреляционные и частные автокорреляционные функции. При логарифмическом преобра- 
Puc. 1. Логарифмическое преобразование данных по анализу оценки приобретения населением медицинских услуг.

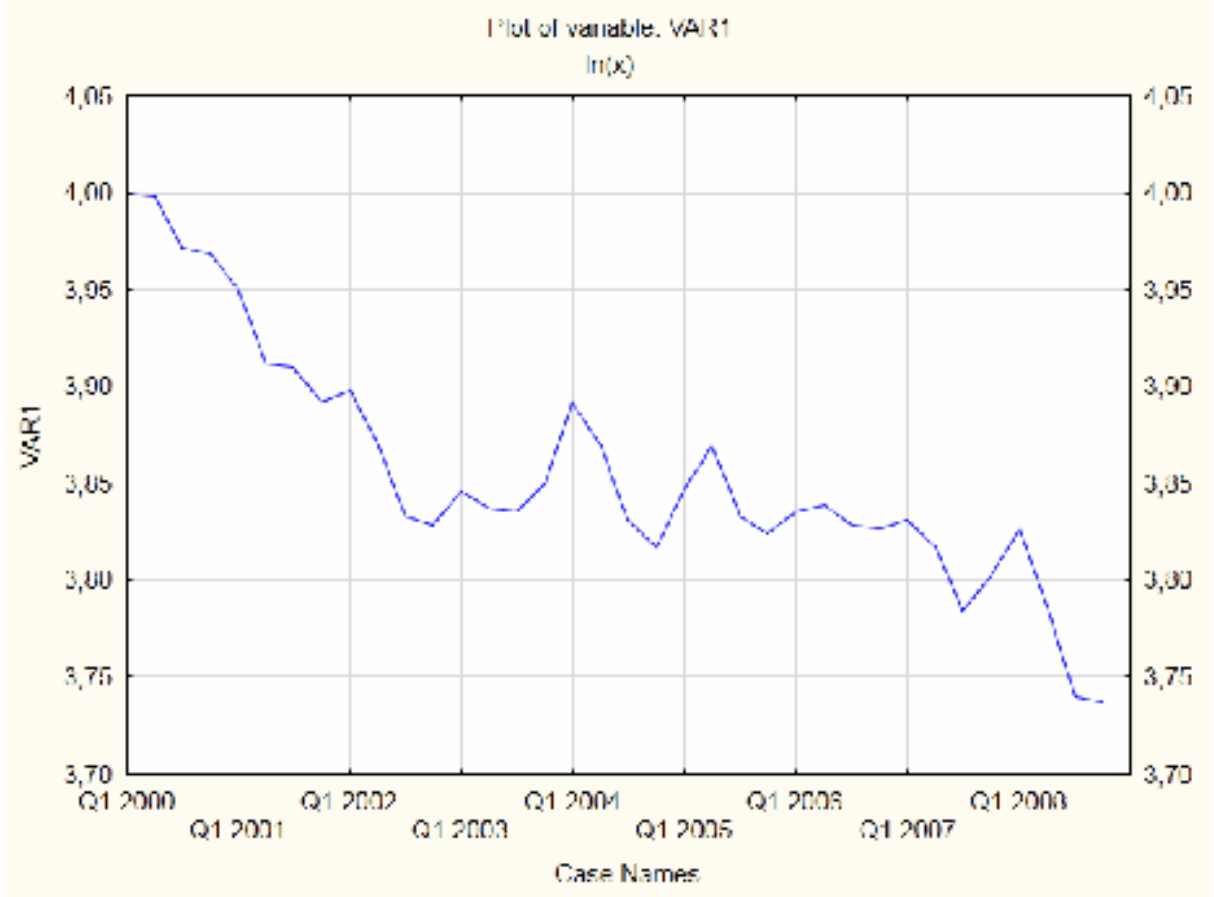

гоприятных условиях развития экономики весьма перспективное будущее. Появившиеся под влиянием кризиса негативные тенденции динамики результатов экономической деятельности страховых компаний в сфере ДМС обусловлены недостаточностью в управлении рисками в указанной сфере.

2. Качественное улучшение взаимодействия страховой компании со структурами ассистанса, лечебно-профилактических учреждений может быть достигнуто лишь при решении организационных вопросов внедрения системы риск-менеджмента.

3. Обоснованный критерий принятия решений при медицинском страховании в условиях риска позволяет получить лишь вероятностные (средневзвешенные) результаты анализа возможных вариантов. 